Gut, 1988, 29, 838-842

Case report

\title{
Long acting somatostatin treatment of paraneoplastic Cushing's syndrome in a case of Zollinger-Ellison syndrome
}

P RUSZNIEWSKI, F GIRARD, R BENAMOUZIG, M MIGNON, AND S BONFILS

From Clinique des Maladies de l' Appareil Digestif, Hôpital Bichat, Paris, France, and Laboratoire de Physiologie, Hopital Trousseau, Paris, France

SUMmary Cushing's syndrome, caused by ectopic ACTH production during Zollinger-Ellison syndrome, raises difficult therapeutic problems. We report a case of clinical and biological efficacy of long acting somatostatin (SMS) in this condition. In a short term study with $200 \mu \mathrm{g}$ SMS bid, symptoms of hypercorticism disappeared while cortisol and ACTH serum concentrations fell below the normal values. Longterm treatment was instituted with $50 \mu \mathrm{g}$ SMS bid. Excellent clinical efficacy as well as normal cortisol and ACTH serum concentrations were maintained during the nine month follow up. Lipotrophic hormone (LPH) serum concentration remained raised. No decrease in size of hepatic metastases was observed. Long acting somatostatin analogues may be useful in endocrine paraneoplastic syndromes.

Cushing's syndrome is not an exceptional feature in the course of Zollinger-Ellison syndrome (ZES). ${ }^{1-3}$ Nevertheless, it raises difficult therapeutic problems, especially in sporadic gastrinomas, where it is associated with widespread metastatic diffusion and very poor prognosis. ${ }^{3}$

Long acting somatostatin analogue SMS 201-995 (mentioned as SMS in the text) has recently been used in various endocrine neoplasia, to control related hormonal hypersecretion(s) and its (their) clinical consequences. ${ }^{+7}$ In the case of ZES, longterm treatment with SMS acts both on the target organ that is, inhibits gastric acid overproduction - and on gastrin tumoral secretion. ${ }^{89}$

We report here the longterm beneficial effects of this substance in the management of Cushing's syndrome occurring in the course of ZES.

Address for correspondence: Dr P Ruszniewski, Clinique des Maladies de l'Appareil Digestif, Hôpital Bichat. 46 rue Huchard, 75877 Paris Cedex 18 , France.

Received for publication 4 December 1987.

\section{Case report}

In 1979 , a 49 year old woman presented with relapsing peptic ulcer and diarrhoea. Zollinger-Ellison syndrome was diagnosed according to the usual criteria: basal acid output $57.6 \mathrm{mmol} / \mathrm{h}$, basal serum gastrin concentration $1167 \mathrm{pg} / \mathrm{ml}$ (normal <100) increasing to $1700 \mathrm{pg} / \mathrm{ml}$ during the secretin infusion test. "' Plasma calcium level was $2.20 \mathrm{mmol} / \mathrm{l}$, with normal urinary cyclic AMP excretion $(0.59 \mu \mathrm{mol} /$ mmol of creatinine, normal $<0.60)$ and normal plasma parathormone level $(64 \mathrm{pg} / \mathrm{ml}$, normal $<76)$. Plasma prolactin concentration (227 mU/l, $130<$ normal $<450$ ) and computed tomography $(C T)$ scan of pituitary fossa were normal. Thus, multiple endocrine neoplasia type I (MEN I) was excluded. Clinical and biological parameters of pituitaryadrenal axis function - that is, plasma cortisol and ACTH concentrations, urinary excretion of 17 hydroxy and ketosteroids, urinary free cortisol were normal. The primary tumour was located by $\mathrm{CT}$ scan in the pancreatic corpus tail junction. Distal 
Table Pretreatment investigation of the pituitary-adrenal axis (normal values in brackets)

\begin{tabular}{|c|c|c|c|}
\hline & $\begin{array}{l}\text { Basal } \\
\text { values }\end{array}$ & $\begin{array}{l}D X M 2 m g / \\
d a y \times 2\end{array}$ & $\begin{array}{l}D X M 8 m g \\
d a y \times 2\end{array}$ \\
\hline \multicolumn{4}{|c|}{ Plasma hormones ( 8 am values) } \\
\hline Cortisol (ng/ml) & $\begin{array}{l}165 \\
(60-12())\end{array}$ & $\begin{array}{c}18.5 \\
(<10)\end{array}$ & $\begin{array}{c}125 \\
(<10)\end{array}$ \\
\hline $\operatorname{ACTH}(\mathrm{pg} / \mathrm{ml})$ & $\begin{array}{l}138 \\
(<10-8(0)\end{array}$ & $\begin{array}{c}142 \\
(<10)\end{array}$ & $\begin{array}{c}114 \\
(<10)\end{array}$ \\
\hline $\mathrm{LPH}(\mathrm{pg} / \mathrm{ml})$ & $\begin{array}{l}2650 \\
(<2()-2(0))\end{array}$ & $\begin{array}{l}2210 \\
(<2(0)\end{array}$ & $\begin{array}{l}1750 \\
(<20)\end{array}$ \\
\hline \multicolumn{4}{|l|}{ Urinary steroid excretion } \\
\hline 17-hydroxysteroids ( $\mathrm{mg} / \mathrm{day}$ ) & $\begin{array}{c}13 \\
(3 \cdot 1-6 \cdot 2)\end{array}$ & & \\
\hline 17-ketosteroids (mg/day) & $\begin{array}{l}15 \\
(6-6 \cdot 2)\end{array}$ & & \\
\hline Free cortisol (pg/day) & $\begin{array}{l}836 \\
(30-10(0)\end{array}$ & & \\
\hline
\end{tabular}

splenopancreatectomy and total gastrectomy were carried out. Four small hepatic metastases were also removed. Serum gastrin concentration decreased to $136 \mathrm{pg} / \mathrm{ml}$ in July 1980 .

In August 1984, serum glucose concentrations rose to $10.0 \mathrm{mmol} / \mathrm{l}$ in the fasting state and to $18.0 \mathrm{mmol} / \mathrm{l}$ one hour after the meal. Serum glucagon concentrations were normal. This diabetes mellitus was attributed to pancreatic excision and treated with 32 units of insulin per day.

From February 1983 to February 1985, serum gastrin concentration rose from $1000 \mathrm{pg} / \mathrm{ml}$ to 5600 $\mathrm{pg} / \mathrm{ml}$. The patient did well during this period, however, and ultrasonography did not show any abnormality. The patient was then referred to our care. Computed tomography scan disclosed two hepatic metastases of $40 \mathrm{~mm}$ in diameter each. Four courses of chemotherapy with Streptozotocin and 5 Fluorouracil were administered, according to Moertel's regimen, "without objective response.

In September 1985, weight gain, lassitude, facial fullness, and mild hypertension $(170 / 100 \mathrm{mmHg})$ were found. There was no abnormal pigmentation. Diabetes mellitus worsened and hypokalaemic alkalosis was noted (serum potassium and bicarbonate concentrations were 2.7 and $32 \mathrm{mmol} / \mathrm{l}$, respectively). Cushing's syndrome was diagnosed on the basis of raised plasma cortisol, ACTH and lipotropic hormone (LPH) concentrations (Table). Cortisol concentrations failed to decrease after a dexamethasone suppression test $(2 \mathrm{mg} /$ day for 48 hours, increasing to $8 \mathrm{mg} /$ day for 48 hours) (Table). X-ray and CT scan of pituitary fossa were normal, as well as adrenal CT scan scintigraphy with iodomethyl-cholesterol.

In respect to the above considerations, SMS treatment was started.

\section{Methods}

The patient was studied at Hôpital Bichat (Paris) before treatment and at 1, 6, 10, 15, 22, 37 weeks after the beginning of the treatment. Clinical examination, abdominal ultrasonography and CT scan were performed. Plasma cortisol' ${ }^{12}$ and urinary free cortisol concentrations were determined by radio-

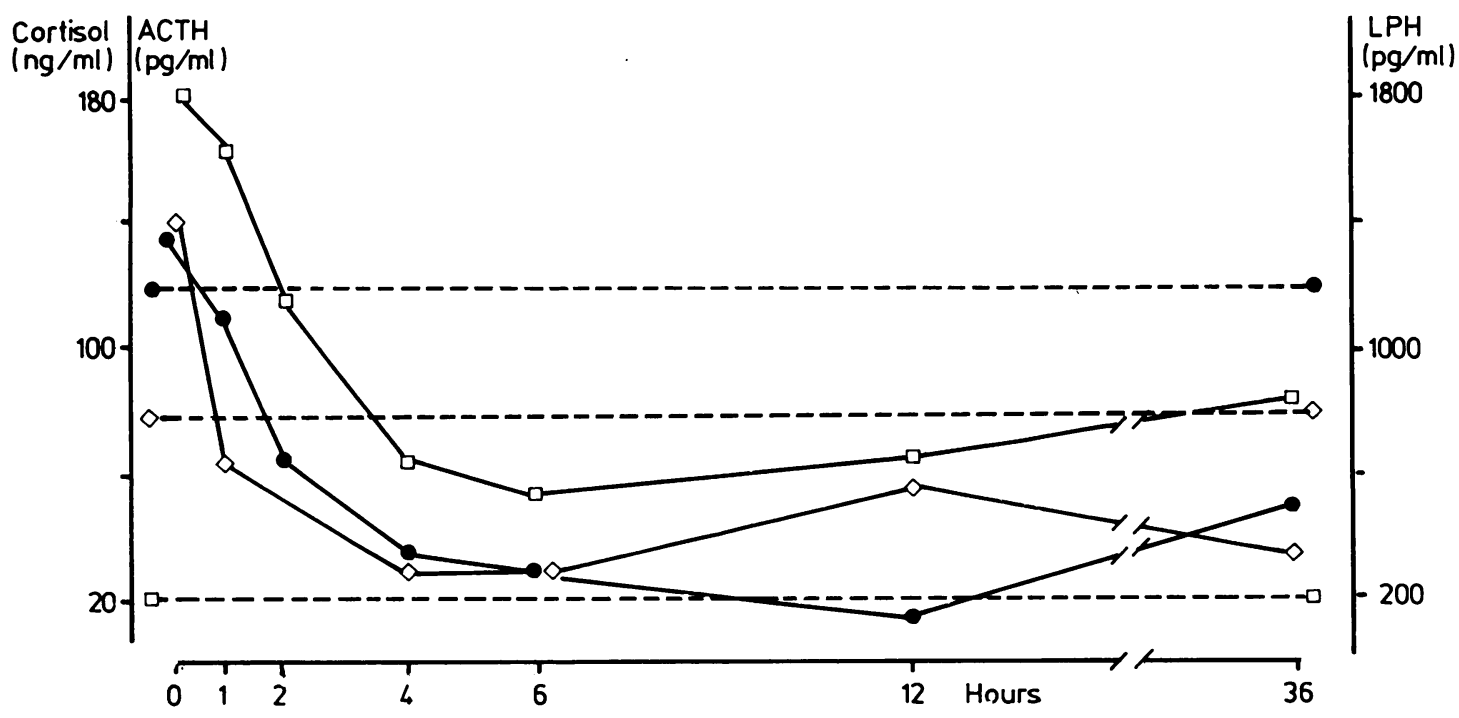

Fig. 1 Effect of a single injection of SMS $(200 \mu \mathrm{gsc})$ on plasma cortisol $(\bigcirc-\bigcirc)$ ACTH $(\diamond-\diamond)$ and $L P H(\square-\square)$ concentrations. Upper limit normal values are represented in dotted lines (cortisol $\bigcirc \bigcirc, A(T H \diamond \cdots \diamond, L P H \square \cdots \square)$. 


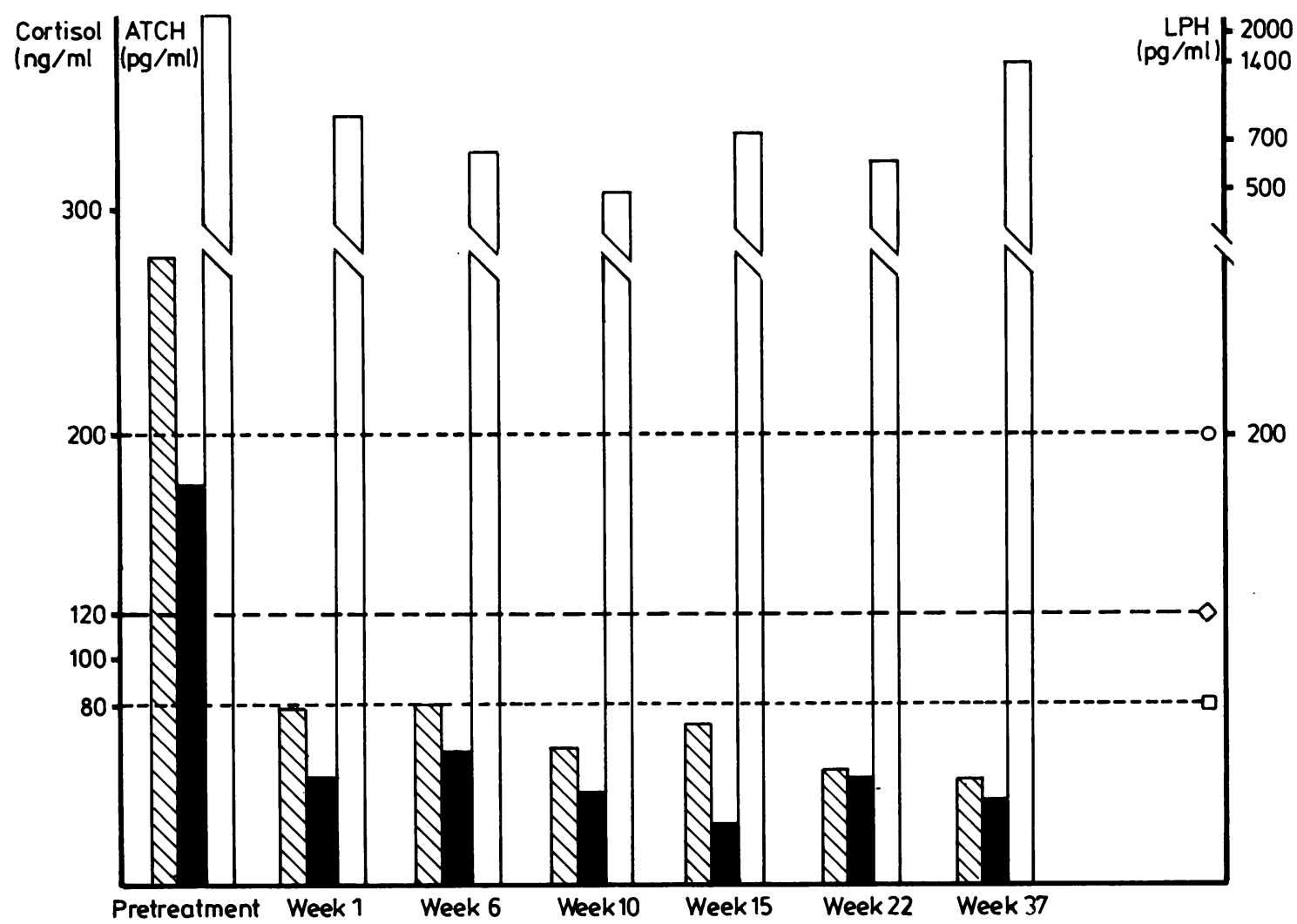

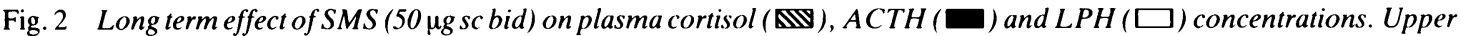
limit normal values are represented in dotted lines (cortisol $\bullet \cdots, A C T H \diamond \cdots \diamond, L P H \square \cdots \square$ ).

competition. Adrenocorticotrophic hormone and LPH concentrations were determined by specific radioimmunoassay. ${ }^{1314}$ Serum gastrin concentrations were measured by radioimmunoassay using rabbit antigastrin antibody (G17) (CA-101, Clinical Assays).

\section{Results}

ACUTE RESULTS AND CHOICE OF DOSAGE FOR LONGTERM TREATMENT

Somatostatin was initially administered at $200 \mu \mathrm{g}$ bid as previously used in ZES to control acid hypersecretion. ${ }^{15}$ In a pilot study, a single injection of SMS caused cortisol and ACTH serum concentrations to fall dramatically; they remained low 36 hours later (Fig. 1).

A three day treatment at the same dosage resulted in an evident clinical improvement with respect to the lassitude and facial fullness; blood pressure was $120 / 80 \mathrm{mmHg}$, without postural hypotension. Serum 8 am cortisol concentration dropped to $30 \mathrm{ng} / \mathrm{ml} \mathrm{-}$ that is, below the normal value $(60-120 \mathrm{ng} / \mathrm{ml}$ ). Serum ACTH and LPH decreased respectively to 37 $\mathrm{pg} / \mathrm{ml}$ and $350 \mathrm{pg} / \mathrm{ml}$. Return of the three hormone concentrations to their pretreatment values was observed 10 days after treatment was discontinued. These results were reproduced during a second test under the same conditions. Thus, on January 1986 , longterm SMS treatment was started. A dosage of $50 \mu \mathrm{g} \mathrm{sc}$ was chosen, lower than usually prescribed, in order to avoid cortisol and ACTH values falling far below the normal ranges.

\section{LONGTERM THERAPEUTIC RESULTS}

The patient rapidly felt better and recovered normal activity. Facial fullness and erythema disappeared, blood pressure $(130 / 80 \mathrm{mmHg})$ and plasma potassium $(3.5 \mathrm{mmol} / \mathrm{l})$ remained normal during the nine-month treatment. Plasma cortisol, ACTH and LPH concentrations iteratively determined by radioimmunoassay promptly decreased (Fig. 2) as did urinary free cortisol, from $2200 \mu \mathrm{g}$ to less than $20 \mu \mathrm{g} / 24$ hours. Simultaneously, serum gastrin concentrations fell 
from 10850 to $309 \mathrm{pg} / \mathrm{ml}$. Size and number of liver metastases estimated by ultrasonography and CT scan at one and three months remained stable, but slightly increased at nine months.

\section{SIDE EFFECTS}

Tolerance of SMS 201-995 was excellent. No local complications at the sites of injection were observed.

Diabetes mellitus improved with a fall of insulin requirement from 32 to 16 UI per day. Faecal fat excretion slightly increased from $7 \cdot 8$ to $15 \mathrm{~g} /$ day.

Other clinical parameters and routine chemical tests were normal.

\section{Discussion}

This case fits within the framework of an ectopic source of ACTH with hypercortisolism not suppressed by high doses of dexamethasone and high circulating levels of ACTH. The simultaneous measurement of lipotropic hormones (beta and gamma LPH) shows a proportionally higher circulating level than might be expected, given ACTH levels. This discrepancy, although not diagnostic, is often noticed in ectopic Cushing's syndrome. ${ }^{\text {It }}$

The dramatic decrease of plasma cortisol and ACTH induced by SMS on three different occasions allows us to rule out the hypothesis of spontaneous fluctuation of the tumoral secretion. The efficacy of SMS in this case is fully documented: the clinical symptoms of Cushing's syndrome disappeared a few days after onset of treatment; plasma cortisol and ACTH returned to strictly normal concentrations in less than four hours; a nine month treatment was able to maintain plasma ACTH and cortisol within the low normal range. During the same time, LPH plasma concentration remained abnormally high.

The effectiveness of short acting somatostatin on ACTH secretion has been shown in man in the cases of pituitary hypersecretion, either in pituitary tumours of Nelson's syndrome ${ }^{17}$ and Cushing's disease $^{18}$ or in Addison's disease. ${ }^{19}$ In vitro, ACTH secretion is reduced by pharmacological doses of somatostatin added to the medium..$^{20}$ The use of the continuous line of mouse pituitary tumour cells (AtT20/D16) confirms this result. ${ }^{2122}$

An increase in number and size of hepatic metastases was noticed at nine months. Indeed, CT scan disclosed four lesions of $60,40,10$, and $10 \mathrm{~mm}$ in diameter respectively. This is at variance with previously published cases where a regression of tumoral volume under SMS was observed. ${ }^{72324}$ This is not invariably the case, however. ${ }^{26}$ Among the various biological signs, only the recent LPH increase may suggest that in the near future higher SMS dosage may be necessary.
In conclusion, SMS appeared in this case to be a valuable and well tolerated drug for the management of paraneoplastic ACTH and LPH over-production in gastrinoma. Discrepancy between dramatic regression of clinical and biological symptoms and lack of tumour regression, suggests that SMS acts mainly at hormone processing level.

We are indebted to Dr M Duet for serum gastrin measurements, and to Mrs M Varin for preparation of the manuscript and excellent technical assistance.

\section{References}

1 Law DH, Liddle GW, Scott HW, Tauber SD. Ectopic production of multiple hormones (ACTH, MSH and gastrin) by a single malignant tumor. $N$ Engl J Med 1965; 273: 292-6.

2 Lyons DF, Eisen BR, Clark MR, Pysher TJ, Welsh JD, Kem DC. Concurrent Cushing's and Zollinger-Ellison syndromes in a patient with islet cell carcinoma. $\mathrm{Am} \mathrm{J}$ Med 1984; 76: 729-33.

3 Maton PN, Gardner JD, Jensen RT. Cushing's syndrome in patients with Zollinger-Ellison syndrome. $N$ Engl J Med 1986; 315: 1-5.

4 Lamberts SWJ, Uitterlinden P, Verschoor L, Van Dongen KT, Del Pozo Z. Long-term treatment of acromegaly with the somatostatin analogue SMS 201-995. N Engl J Med 1985; 313: 1576-80.

5 Boden G, Ryan IG, Eisenschmid BL, Shelmet JJ, Owen OE. Treatment of inoperable glucagonoma with the long-acting somatostatin analogue SMS 201-995. N Engl J Med 1986; 314: 1686-9.

6 Ch'ng JL, Anderson JV, Williams SJ, Carr DH, Bloom SR. Remission of symptoms during long-term treatment of metastatic pancreatic endocrine tumours with longacting somatostatin analogue. $\mathrm{Br}$ Med J 1986; 292: 981-2.

7 Kraenzlin ME, Ch’ng JLC, Wood SM, Carr DH, Bloom SR. Long-term treatment of a vipoma with somatostatin analogue resulting in remission of symptoms and possible shrinkage of metastases. Gastroenterology 1985; 8: $185-7$.

8 Bonfils S, Ruszniewski P, Costil V, et al. Prolonged treatment of Zollinger-Ellison syndrome by long-acting somatostatin. Lancet 1986; i: 554-5.

9 Ellison EC, O’Dorisio TM, Sparks J, et al. Observations on the effect of a somatostatin analog in the ZollingerEllison syndrome: implications for the treatment of apudomas. Surgery 1986; 100: 437-43.

10 Mignon M, Ruszniewski P, Haffar S, Rigaud D, Rene E, Bonfils S. Current approach to the management of tumoral process in patients with gastrinoma. World $J$ Surg 1986; 10: 703-10.

11 Moertel CG, Hanley JA, Johnson LA. Streptozotocin alone compared with streptozotocin plus fluorouracil in the treatment of advanced islet-cell carcinoma. $N$ Engl J Med 1980; 303: 1189-95.

12 Pham Huu Trung MT. Dosage du cortisol plasmatique par liaison compétitive de la transcortine. Ann Biol Clin 1970; 29: 145-52. 
13 Proeschel MF, Courvalin JC, Donnadieu M, Binoux M, Girard F. Preparation and evaluation of ACTH antibodies. Acta Endocrinol (Copenh) 1974; 75: 461-77.

14 Bertagna X, Luton JP, Binoux M, Bricaire H, Girard F. Characterization of lipotropin-, corticotropin-, and -endorphine immunoreactive materials secreted in vitro by a human pituitary adenoma responsible for a case of Nelson's syndrome. J Clin Endocrinol Metab 1979; 49: 527-32.

15 Bonfils S, Ruszniewski Ph, Laucournet H, Costil V, Rene E, Mignon M. Long-term treatment management of Zollinger-Ellison syndrome with SMS 201-995, a long-lasting somatostatin analog. Can J Physiol Pharm 1986: 63. Symposium on Gastrointestinal Hormones, Vancouver.

16 Kuhn JM, Luton JP, Bricaire H. ACTH, bétaendorphine, lipotropines; étude physiopathologique chez l'homme. Ann Med Intern 1982; 133: 148-51.

17 Tyrrell JB, Lorenzi M, Gehrich JE, Forsham PH. Inhibition by somatostatin of ACTH secretion in Nelson's syndrome. J Clin Endocrinol Metab 1975; 40: 1125-7.

18 Calderon MD, Martinez De Osaba MJ, Palacin A,
Vilardell E. Macroadenoma hipofisario secretor de ACTH: efecto inhibidor de la ciproheptadina y la somatostatina. Med Clin (Barc) 1984; 82: 723-6.

19 Fehm JL, Voigt KH, Lang R, Beinert KE, Raptis S, Pfeiffer EF. Somatostatin: a potent inhibitor of ACTH hypersecretion in adrenal insufficiency. Klin Wochenschr 1976; 54: 173-5.

20 Maruyama $T$, Ishikawa $H$. Somatostatin: its inhibitory effect on the release of hormones and $\mathrm{IgG}$ from clonal cells strains. Its Ca-influx dependance. Biochem Biophys Res Commun 1977; 74: 1083-8.

21 Richardson UI, Schonbrunn A. Inhibition of adrenocorticotropin secretion by somatostatin in pituitary cells in culture. Endocrinology 1981; 108: 281-90.

22 Reisin T. Multiple mechanisms of somatostatin inhibition of adrenocorticotropin release from mouse anterior pituitary cells. Endocrinology 1985; 116: 2259-66.

23 Shepherd JJ, Senator GB. Regression of liver metastases in patient with gastrin-secreting tumour treated with SMS 201-995. Lancet 1986; i: 574.

24 Clements D, Elias E. Regression of metastatic vipoma with somatostatin analogue SMS 201-995. Lancet 1985; i: 874 . 